\title{
Thermal Time as a Bioclimatic Index for Development Characterization of Sunflower Cultivars in Southern Brazil
}

\author{
${ }^{1}$ Maurício Siqueira dos Santos, ${ }^{2}$ Diego Nicolau Follmann, ${ }^{3}$ Astor Henrique Nied, ${ }^{4}$ Cleiton Antônio Wartha, ${ }^{5}$ Vívian \\ Oliveira Costa, ${ }^{6}$ Éder Neimar Plautz, ${ }^{7}$ Darlei München Bamberg, ${ }^{8}$ João Vitor Ferreira Scopel, ${ }^{9}$ Gustavo Henrique Engel
}

${ }^{1}$ Department of Crop Science, Federal University of Santa Maria, Santa Maria, Brazil

${ }^{2}$ Department of Crop Science, Federal University of Santa Maria, Santa Maria, Brazil

${ }^{3}$ Department of Crop Science, Federal University of Santa Maria, Santa Maria, Brazil

${ }^{4}$ Graduate Program in Applied Plant Sciences, University of Minnesota, St. Paul, United States

${ }_{6}^{5}$ Department of Crop Science, Federal University of Santa Maria, Santa Maria, Brazil

${ }^{6}$ Department of Crop Science, Federal University of Santa Maria, Santa Maria, Brazil

${ }^{7}$ Department of Crop Science, Federal University of Santa Maria, Santa Maria, Brazil

${ }^{8}$ Department of Crop Science, Federal University of Santa Maria, Santa Maria, Brazil

${ }^{9}$ Department of Crop Science, Federal University of Santa Maria, Santa Maria, Brazil

Correspondence Author: Diego Nicolau Follmann, Avenida Roraima, $\mathrm{n}^{\circ}$ 1000, Bairro Camobi, CEP 97105-900, Santa Maria, RS, Brazil. Tel: +55(55) 32208899.

E-mail: diegonicolaufollmann@gmail.com

Received date: 12 August 2018, Accepted date: 15 November 2018, Online date: 27 November 2018

Copyright: ( 2018 Maurício Siqueira dos Santos, et al, This is an open-access article distributed under the terms of the Creative Commons Attribution License, which permits unrestricted use, distribution, and reproduction in any medium, provided the original author and source are credited.

\begin{abstract}
Sunflower is widespread in several regions of the world, being an important source of vegetable oil and protein feed for livestock. The modern sunflower cultivars are insensitive to photoperiod responses, with growth and development being influenced by the air temperature and accumulated degree days (thermal time). The aim of this study was to evaluate thermal time in comparison to calendar days for the change of phenological stages of sunflower cultivars in Santa Maria, Rio Grande do Sul, Brazil. The evaluated cultivars were Syn 045, BRS 323, BRS G58, BRS G59, BRS G60, BRS G61, MULTISSOL 02 and CATISSOL 03. The experiment was performed in a randomized block design and subperiods were defined from the emergence the crop reproductive stages, corresponding to the stages R3, R4, R5.1, R5.10, R6, R7, R8 and R9. Thermal time was calculated by means of the residual method, a method widely used to determine the thermal time in annual crops. There were variations in the thermal time between cultivars with respect to development stages, depending on the subperiod and evaluated cultivars. There was a difference in cultivar group formation if the thermal time measurement was used as a substitute for calendar days. The cultivar Syn 045 presented the greatest thermal time in both stages, followed by cultivar BRS G61 that presented the second greater thermal time for stage transition, indicating a late cycle behavior in relation to the other cultivars. Studying the behavior of sunflower genotypes in face of the accumulation of degrees day and determining their thermal time enables better understanding of the crop as well as its development stages, allowing the best planning of the cultural practices and sunflower management in the reproductive stage.
\end{abstract}

Key words: Helianthus annuus L., Thermal time, Development stages.

\section{INTRODUCTION}

Sunflower (Helianthus annuus L.) is a plant characterized by its industrial versatility and climatic adaptability (Aquino et al., 2010). According to Monteiro (2009), sunflower uses may vary from ornamental, medicinal, honey production, and green manure. However, sunflower stands out in the vegetable oil production, varying from 30 to $56 \%$ of oil in its achenes. Morphological traits such as rapid growth, rectilinear and not rough stem and little branched in the apex are characteristic of the species presented by Dalchiavon et al. (2015).

The crop flexibility, with modern cultivars insensible to photoperiod response and responsive to the thermal time and the well-defined and relatively short cycle, ranging from 65 to 165 days (Pimentel and Borém, 2018), make the sunflower a propitious crop as a secondary cropping in agricultural production systems. Therefore, sunflower is easily employed in crop rotation systems, diversifying agricultural production.

The sunflower development is affected by the air temperature, requiring the accumulation of degrees day for the change of phenological stages and thus complete its development. The use of thermal time allows greater precision on planning the crop management practices than when based on calendar days (Bergamaschi and Bergonci, 2017).

Sentelhas and Ungaro (1998) assessed bioclimatic indexes of sunflower crop and concluded that the thermal time presented the lowest total variability in comparison to other indexes, being deployed to study the phenology of Brazilian sunflower cultivars. Other researches were also developed based on thermal time in sunflower (Lucas et al., 2015, Souza et al., 2016), potato (Paula et al., 2005), watermelon (Trentin et al. 2008), maize (Deprá et al., 2016), common bean (Miranda and Junior, 2010), rice (Bartz et al., 2017, Steinmetz et al., 2017), grapevine (Tomazetti et al., 2015), and coffee (Carvalho et al., 2014). 
Sunflower development for cropping in a subtropical environment climate presents different responses due to different thermal time among cultivars. Studying the sunflower crop development in function of its thermal time is important to generate information used in the cultivar recommendation, since the sowing of cultivars with different vegetative cycles reduces the risks of potential yield losses in function of thermal and water stress. In this sense, studies for the environment with the cultivars addressed in this study were not found in the literature. Therefore, the aim of this study was to evaluate thermal time in comparison to calendar days for the change of phenological stages of sunflower cultivars in Santa Maria, Rio Grande do Sul, Brazil.

\section{MATERIALS AND METHODS}

The experiment was carried out at the Federal University of Santa Maria (UFSM) in Santa Maria (latitude $29^{\circ} 41^{\prime} \mathrm{S}$, longitude $53^{\circ} 42^{\prime} \mathrm{W}$ and $90 \mathrm{~m}$ altitude), Rio Grande do Sul state, southern Brazil. According to the Köppen climate classification, the climate is Cfa, subtropical humid, with hot summers and without dry season defined (Alvares et al., 2013). The soil of the experimental area is classified as sandy loam typic Paleudalf (Embrapa, 2013), presenting proper drainage in a coxilha-knoll site. According to the chemical and physical analysis, the soil presented the following contents: clay $=19 \%$, organic matter $=1.9 \%$, base saturation $=40.5 \%, \mathrm{pH}=4.8, \mathrm{P}=22.6 \mathrm{mg} / \mathrm{dm}^{3}, \mathrm{~K}=72.0 \mathrm{mg} / \mathrm{dm}^{3}$ and $\mathrm{B}=0.4 \mathrm{mg} / \mathrm{dm}^{3}$.

Eight treatments were used for experiment implantation, corresponding to the sunflower cultivars that compose the Brazilian National Sunflower Trial: Syn 045, BRS 323, BRS G58, BRS G59, BRS G60, BRS G61, Multisol 02 and Catissol 03. Sowing procedure occurred on September 12, 2017, a period comprised within the recommended sowing dates for the Santa Maria region.

The experiment was developed in a randomized block design. The experimental area was divided into four blocks (replicates), which were subdivided into experimental units (plots) with an area of $21.6 \mathrm{~m}^{2}(6 \mathrm{~m} \times 3.6 \mathrm{~m})$ and useful area of $8.2 \mathrm{~m}^{2}$. The sowing density was 45,000 plants ha ${ }^{-1}$ and the row spacing used was $0.9 \mathrm{~m}$. The basic fertilization procedure was performed based on soil analysis, with $400 \mathrm{~kg} \mathrm{ha}^{-1}$ of formulated chemical fertilizer (NPK in proportion of 5-20-20) distributed at the sowing rows. Moreover, $31.5 \mathrm{~kg} \mathrm{ha}^{-1}$ of nitrogen and $2 \mathrm{~kg} \mathrm{ha}^{-1}$ of boron were broadcasted at 25 days after emergence.

The phenological phases (phenophase) were evaluated daily based on the crop activity index. Bencke and Morellato (2002) described the activity index as the simplest method for the evaluation of phenological phases, where only the absence or presence of the phenophase in the individual is verified, without estimating the intensity of the phase occurrence. During the plant reproductive phase, the development stages R3, R4, R5.1, R5.10, R6, R7, R8 and R9 were evaluated based on the description determined by Schneiter and Miller (1981) and presented in "Phases of Development in Sunflower", (Embrapa, 1997). The change of stage was considered when $50 \%$ of total number of plants of the plot reached the following stage.

The meteorological data used were taken from the National Meteorological Institute (INMET) database, with automatic meteorological station located at 1,554 meters from the experimental area in Santa Maria - RS. The thermal time was calculated based on seedling emergence by the residual method. According to Bergamaschi and Bergonci (2017), the method consists of calculating the plant thermal time through the difference between the mean daily air temperature and the crop lowest base temperature. The method used for the calculation is demonstrated by TTd $=\sum(T m e d-T b)$, with TTd as the daily thermal time accumulated ( ${ }^{\circ}$ day), Tmed as the mean daily air temperature $\left({ }^{\circ} \mathrm{C}\right)$ and $\mathrm{Tb}$ as the crop lowest base temperature $\left({ }^{\circ} \mathrm{C}\right)$. Sangoi and Silva $(1986)$ found the sunflower lower base temperature equal to $7.2^{\circ} \mathrm{C}$.

For thermal time and days after emergence based on calendar days, analysis of variance and F-tests were performed for block and cultivar effects at $5 \%$ error probability. Mean comparison of the genotypes was performed with the aid of the Scott Knott test at 5\% of probability. Data statistical analysis was performed using the Sisvar statistical software.

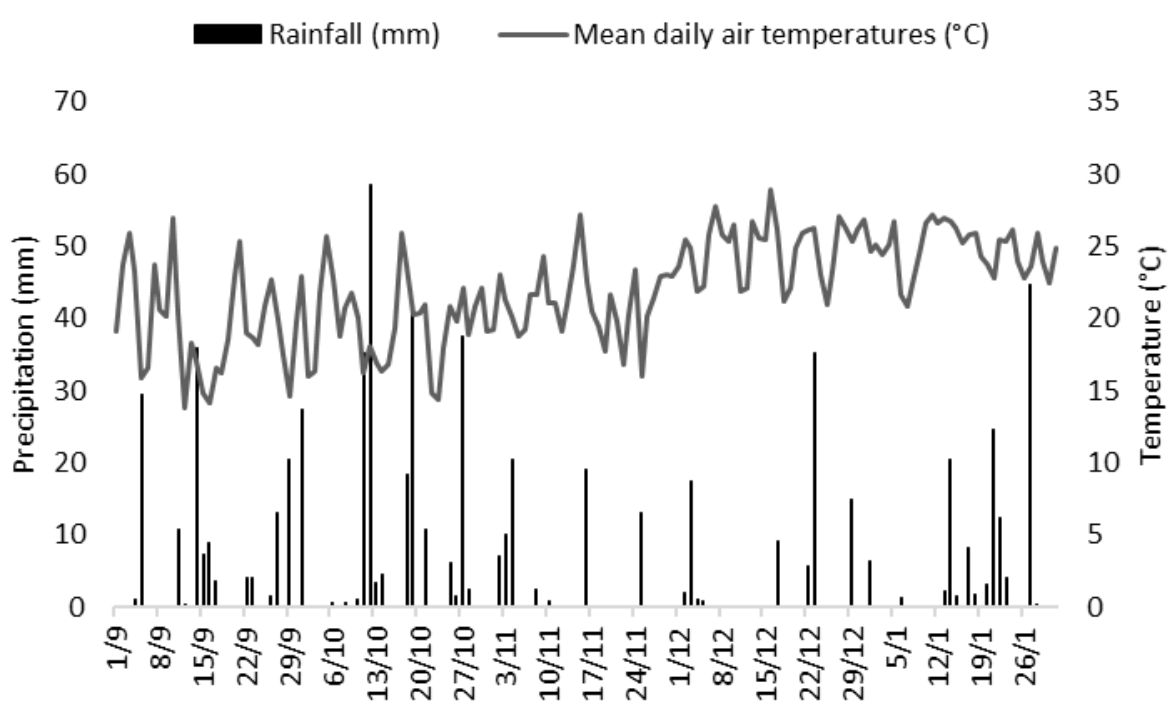

Figure 1. Mean daily air temperatures $\left({ }^{\circ} \mathrm{C}\right)$ and mean rainfall $(\mathrm{mm})$ during $2017 / 2018$ agricultural year.

\section{RESULTS}

The results obtained from the analysis of variance demonstrated significant differences for the thermal time and calendar days in all development stages at $5 \%$ error probability (Table 1). The experimental precision represented by the coefficient of variation, indicated high reliability and precision of the observed data. During the experiment, the meteorological conditions were favorable for the sunflower crop development, with absent air temperature and rainfall oscillations, being considered within normal for the region under study. The eight sunflower cultivars evaluated in the experiment exhibited group formation at all development stages (R3 to R9) for thermal time and calendar days (Table 2). The mean required to reach the R3 stage was 651.38 ( ${ }^{\circ} \mathrm{C}$ day), ranging from 611.59 for cultivar BRS 323 to $752.56\left({ }^{\circ} \mathrm{C}\right.$ day) for cultivar Syn 045. On calendar days, the mean required to reach the R3 stage was 51 days (days after emergence), with cultivar BRS 323 requiring 48.21 days and Syn 045 with 58 days, implying a 9-day difference between these cultivars. Three groups were formed, and the same behavior was observed for both thermal time and calendar days. The group represented by the cultivars with the greatest thermal time was formed by Syn 045 and the group 2 was composed by the cultivar BRS G61. Moreover, group 3 was integrated by cultivars BRS 323, BRS G58, BRS G59, BRS G60, MULTISSOL 02 and CATISSOL 03 . 
Citation: Maurício Siqueira dos Santos et al., 2018. Thermal Time As A Bioclimatic Index For Development Characterization Of Sunflower Cultivars In Southern Brazil, Australian Journal of Basic and Applied Sciences. 12(11): 64-67. DOI: 10.22587/ajbas.2018.12.11.13

Table 1: Summary of the analysis of variance for the thermal time and calendar days from emergence to R3 to R9 phenological stages of sunflower cultivars in Santa Maria - RS, 2018.

\begin{tabular}{|c|c|c|c|c|c|c|c|c|c|}
\hline \multirow{2}{*}{$\begin{array}{l}\text { Source of } \\
\text { Variation }\end{array}$} & \multirow[t]{2}{*}{ df } & \multicolumn{8}{|c|}{ Mean Squares for thermal time } \\
\hline & & $\mathbf{R 3}$ & $\mathbf{R 4}$ & R5.1 & R5.10 & R6 & R7 & R8 & R9 \\
\hline Blocks & 3 & 127.75 & 519.83 & 103.63 & 632.65 & 123.96 & 634.67 & $2,427.35$ & $1,323.57$ \\
\hline Treatments & 7 & $10,784.54 *$ & $9,091.61 *$ & $11,796.23 *$ & $16,292.54 *$ & $19,201.31 *$ & $31,519.44 *$ & $23,566.50^{*}$ & $36,257.38^{*}$ \\
\hline Resisual & 21 & 170.51 & 104.42 & 299.71 & 187.42 & 312.72 & $1,208.99$ & 886.52 & $1,087.08$ \\
\hline CV (\%) & & 2.00 & 1.45 & 2.20 & 1.53 & 1.89 & 3.39 & 2.61 & 2.65 \\
\hline \multirow{2}{*}{$\begin{array}{l}\text { Source of } \\
\text { Variation }\end{array}$} & \multirow[t]{2}{*}{$\mathrm{df}$} & \multicolumn{8}{|c|}{ Mean Squares for calendar days } \\
\hline & & R3 & R4 & R5.1 & R5.10 & R6 & R7 & R8 & R9 \\
\hline Blocks & 3 & 0.91 & 3.71 & 0.70 & 2.11 & 0.53 & 1.08 & 9.21 & 6.28 \\
\hline Treatments & 7 & 49.71* & $49.27 *$ & $63.14 *$ & $51.00 *$ & $57.71 *$ & $94.50 *$ & $69.48 *$ & $106.25^{*}$ \\
\hline Resisual & 21 & 0.91 & 0.47 & 1.41 & 0.64 & 0.98 & 3.49 & 2.71 & 3.42 \\
\hline $\mathrm{CV}(\%)$ & & 1.88 & 1.25 & 1.96 & 1.16 & 1.40 & 2.45 & 1.99 & 2.10 \\
\hline
\end{tabular}

* Significant by the F-test at $5 \%$ error probability.

Table 2: Means for the thermal time (in ${ }^{\circ} \mathrm{C}$ day) and calendar days (days after emergence) from emergence to phenological stages R3, R5, R5.10, R6, R7, R8, R9 for eight sunflower cultivars in Santa Maria - RS, 2018.

\begin{tabular}{|l|l|l|l|l|l|l|l|l|}
\hline \multirow{2}{*}{ Cultivars } & \multicolumn{9}{|c|}{ Thermal time $\left({ }^{\circ} \mathbf{C}\right.$ day $)$} \\
\cline { 2 - 9 } & R3 & R4 & R5.1 & R5.10 & R6 & R7 & R8 & R9 \\
\hline Syn 045 & $752.56 \mathrm{a}$ & $803.23 \mathrm{a}$ & $882.74 \mathrm{a}$ & $1,025.19 \mathrm{a}$ & $1,073.50 \mathrm{a}$ & $1,173.10 \mathrm{a}$ & $1,306.54 \mathrm{a}$ & $1,465.83 \mathrm{a}$ \\
\hline BRS 323 & $611.59 \mathrm{c}$ & $678.21 \mathrm{c}$ & $753.78 \mathrm{~d}$ & $848.63 \mathrm{~d}$ & $883.41 \mathrm{c}$ & $954.33 \mathrm{c}$ & $1,116.58 \mathrm{c}$ & $1,206.00 \mathrm{c}$ \\
\hline BRS G58 & $629.01 \mathrm{c}$ & $675.28 \mathrm{c}$ & $741.43 \mathrm{~d}$ & $841.75 \mathrm{~d}$ & $884.40 \mathrm{c}$ & $912.63 \mathrm{c}$ & $1,065.48 \mathrm{c}$ & $1,179.93 \mathrm{c}$ \\
\hline BRS G59 & $622.55 \mathrm{c}$ & $680.26 \mathrm{c}$ & $747.68 \mathrm{~d}$ & $876.48 \mathrm{c}$ & $900.29 \mathrm{c}$ & $997.10 \mathrm{c}$ & $1,129.30 \mathrm{~b}$ & $1,214.68 \mathrm{c}$ \\
\hline BRS G60 & $632.49 \mathrm{c}$ & $685.25 \mathrm{c}$ & $751.30 \mathrm{~d}$ & $872.58 \mathrm{c}$ & $900.29 \mathrm{c}$ & $951.49 \mathrm{c}$ & $1,075.70 \mathrm{c}$ & $1,174.49 \mathrm{c}$ \\
\hline BRS G61 & $713.43 \mathrm{~b}$ & $758.09 \mathrm{~b}$ & $857.15 \mathrm{~b}$ & $962.58 \mathrm{~b}$ & $1,007.46 \mathrm{~b}$ & $1,109.34 \mathrm{~b}$ & $1,174.66 \mathrm{~b}$ & $1,268.81 \mathrm{~b}$ \\
\hline MULTISSOL 02 & $617.94 \mathrm{c}$ & $681.06 \mathrm{c}$ & $763.36 \mathrm{~d}$ & $862.56 \mathrm{c}$ & $898.06 \mathrm{c}$ & $1,059.99 \mathrm{~b}$ & $1,103.20 \mathrm{c}$ & $1,195.91 \mathrm{c}$ \\
\hline CATISSOL 03 & $631.50 \mathrm{c}$ & $688.25 \mathrm{c}$ & $789.51 \mathrm{c}$ & $883.43 \mathrm{c}$ & $921.24 \mathrm{c}$ & $1,058.41 \mathrm{~b}$ & $1,165.18 \mathrm{~b}$ & $1,234.39 \mathrm{~b}$ \\
\hline Mean & 651.38 & 706.21 & 785.87 & 896.65 & 933.58 & $1,027.05$ & $1,142.08$ & $1,242.50$ \\
\hline
\end{tabular}

\begin{tabular}{|l|l|l|l|l|l|l|l|l|}
\hline \multirow{2}{*}{ Cultivars } & \multicolumn{9}{|c|}{ Calendar days from emergence to phenological stages } \\
\cline { 2 - 9 } & R3 & R4 & R5.1 & R5.10 & R6 & R7 & R8 & R9 \\
\hline Syn 045 & $58.00 \mathrm{a}$ & $62.25 \mathrm{a}$ & $67.25 \mathrm{a}$ & $75.50 \mathrm{a}$ & $78.25 \mathrm{a}$ & $83.75 \mathrm{a}$ & $91.50 \mathrm{a}$ & $100.25 \mathrm{a}$ \\
\hline BRS 323 & $48.25 \mathrm{c}$ & $53.00 \mathrm{c}$ & $58.25 \mathrm{c}$ & $65.75 \mathrm{~d}$ & $68.00 \mathrm{c}$ & $72.25 \mathrm{~d}$ & $81.50 \mathrm{c}$ & $86.25 \mathrm{c}$ \\
\hline BRS G58 & $49.50 \mathrm{c}$ & $52.75 \mathrm{c}$ & $57.25 \mathrm{c}$ & $65.25 \mathrm{~d}$ & $68.00 \mathrm{c}$ & $69.75 \mathrm{~d}$ & $78.25 \mathrm{~d}$ & $84.75 \mathrm{c}$ \\
\hline BRS G59 & $49.00 \mathrm{c}$ & $53.00 \mathrm{c}$ & $57.75 \mathrm{c}$ & $67.50 \mathrm{c}$ & $69.00 \mathrm{c}$ & $74.75 \mathrm{c}$ & $82.00 \mathrm{c}$ & $86.75 \mathrm{c}$ \\
\hline BRS G60 & $49.75 \mathrm{c}$ & $53.25 \mathrm{c}$ & $58.00 \mathrm{c}$ & $67.25 \mathrm{c}$ & $69.00 \mathrm{c}$ & $72.00 \mathrm{~d}$ & $79.00 \mathrm{~d}$ & $84.50 \mathrm{c}$ \\
\hline BRS G61 & $55.00 \mathrm{~b}$ & $58.50 \mathrm{~b}$ & $66.25 \mathrm{a}$ & $72.75 \mathrm{~b}$ & $75.25 \mathrm{~b}$ & $81.00 \mathrm{a}$ & $84.50 \mathrm{~b}$ & $90.00 \mathrm{~b}$ \\
\hline MULTISSOL 02 & $48.75 \mathrm{c}$ & $53.25 \mathrm{c}$ & $59.00 \mathrm{c}$ & $66.75 \mathrm{c}$ & $69.00 \mathrm{c}$ & $78.25 \mathrm{~b}$ & $80.75 \mathrm{~d}$ & $85.75 \mathrm{c}$ \\
\hline CATISSOL 03 & $49.75 \mathrm{c}$ & $53.50 \mathrm{c}$ & $61.00 \mathrm{~b}$ & $68.00 \mathrm{c}$ & $70.25 \mathrm{c}$ & $78.25 \mathrm{~b}$ & $84.00 \mathrm{~b}$ & $88.0 \mathrm{~b}$ \\
\hline Mean & 51.00 & 54.94 & 60.59 & 68.59 & 70.84 & 76.25 & 82.69 & 88.28 \\
\hline
\end{tabular}

*Means followed by the same letter in the column do not differ from each other by the Scott-Knott test $(\mathrm{p}>0.05)$.

Meanwhile for R4 phenological stage, similar behavior was observed with the formation of the same groups in both conditions. For the R5.1 stage, the Syn 045 cultivar presented the greatest thermal time to reach the development stage, followed by the cultivar BRS G61 (group 2), while group 3 was composed by the cultivar CATISSOL 03 and group 4 by cultivars BRS G59, BRS G60 and MULTISSOL 02. Regarding calendar days for the R5.1 stage, three groups were formed: the first one formed by the cultivars Syn 045 and BRS G61, second group formed by the cultivar CATISSOL 03, and, the third group formed by cultivars BRS 323, BRS G58, BRS G59, BRS G60 and MULTISSOL 02. Therefore, these findings demonstrated that there are differences for those conditions at the R5.1 development stage.

Four groups were formed for the end of flowering (R5.10 stage). The first group was composed by cultivar Syn 045 and the second by BRS G61. Moreover, group 3 comprised cultivars BRS G59, BRS G60, MULTISSOL 02 and CATISSOL 03 and the last group was formed by cultivars BRS 323 and BRS G58. The same classification was observed at the end of flowering for calendar days. Furthermore, the R6 stage also exhibited the same behavior between thermal time and calendar days. From the beginning to the end of anthesis (R5.1 to R5.10), the cultivar Syn 045 was the cultivar with the greatest thermal time, followed by the cultivar BRS G61, whereas the cultivars BRS 323 and BRS G58 were the cultivars with lower thermal time to reach these development stages.

The R7 stage corresponds to the beginning of grain filling, being considered a substantial stage for grain yield and highlighting the time of genetic variability for reproductive cycle among sunflower cultivars. Three groups were formed for thermal time: group 1 was composed by Syn 045, group 2 by cultivars BRS G61, MULTISSOL 02 and CATISSOL 03, and group 3 was formed by cultivars BRS 323, BRS G58, BRS G59 and BRS G60. The beginning of grain filling presented another group formation for the calendar days, with the formation of four groups. Therefore, the group with the most days of emergence to flowering included the cultivars Syn 045 and BRS G61, group 2 contained the cultivars MULTISSOL 02 and CATISSOL 03. Furthermore, group 3 was formed by cultivar BRS G59 and group 4 by cultivars BRS 323, BRS G58 and BRS G60.

Three groups were formed for the thermal time at the R8 stage. The group 1 presented the greatest thermal time with Syn 045 , while group 2 comprised the cultivars BRS G59 and BRS G61 and CATISSOL 03. Whereas, the group with the lower thermal time to reach the R8 stage was composed by cultivars BRS 323 , BRS G58, BRS G60 and MULTISSOL 02. Calendar days presented a different classification in comparison to thermal time for the R8 stage, with the formation of four groups. Thereby, group 1 was represented by the cultivar Syn 045, with the highest number of days, followed by group 2 with BRS G61 and CATISSOL 03, group 3 with cultivar BRS 323 and group 4 by cultivars BRS G58, BRS G60 and MULTISSOL 02.

The R9 stage represents the sunflower physiological maturation, where there is no more photoassimilates exchange between the plant and achenes. At this stage, three groups were formed for the thermal time. Moreover, the group with the greatest thermal time was formed by Syn 045, indicating the same trend as less precocious cultivars among the eight evaluated cultivars. This finding was also confirmed in the other crop development stages. Group 2 was formed by cultivar G61 and CATISSOL 03, which can be considered the following cultivars with the later cycle, and the third group was composed by the cultivars with the lowest thermal time, being BRS 323, BRS G58, BRS G59, BRS G60 and MULTISSOL 02. Three groups were also formed for calendar days and there were no changes in the classification among the cultivars. 
Citation: Maurício Siqueira dos Santos et al., 2018. Thermal Time As A Bioclimatic Index For Development Characterization Of Sunflower Cultivars In Southern Brazil, Australian Journal of Basic and Applied Sciences. 12(11): 64-67. DOI: 10.22587/ajbas.2018.12.11.13

The air temperature is the factor that regulates the plant development stages, given as a function of the thermal time, with direct effects on the phenology and determining the anticipation or delay in development (Ferreira, 2016). For this reason, the use of thermal time rather than calendar days becomes more appropriate (Bergamaschi and Bergonci, 2017). Otherwise, changes in crop cycle length may occur depending on the growing location.

Corroborating this information, differences between measurements were observed in group formation for the R5.1, R7 and R8 stages when using the thermal time in comparison to calendar days. In this sense, the thermal time use as a reference is desirable if relative temperature data is available in a location nearby the experimental area. This measurement exhibits proper response in sunflower crop development (Sentelhas and Ungaro, 1998).

According to Souza et al. (2016), the thermal time is an attractive and widely used method to represent biological time in plants. Studies on the thermal time were developed in many crops (Bartz et al., 2017; Carvalho et al., 2014; Deprá et al., 2016; Miranda and Junior, 2010; Lucas et al., 2015; Paula et al., 2005; Steinmetz et al., 2017; Tomazetti et al., 2015; Trentin et al., 2008).

In addition to comprehending the dynamics of thermal time in sunflower cultivars, the choice of cultivars for crop positioning is a very important step for the success of a commercial crop. Moreover, sowing time is limited in preferential crop dates within a crop rotation system due to factors such as the water availability in the soil and periods with excessive rainfall, which hamper the mechanization of the area. In this sense, the use of cultivars with different thermal times to reach the phenological stages is recommended for farmers aiming to reduce the risk of elevated yield losses under water deficit conditions during critical periods, such as flowering and grain filling.

The cultivar Syn 045 was the cultivar that presented the greatest thermal time to reach the complete anthesis $\left(1,025.19^{\circ} \mathrm{C}\right.$ for the R5.10 stage), beginning of the achenes filling $\left(1,173.10^{\circ} \mathrm{C}\right.$ for the $\mathrm{R} 7$ stage) and physiological maturation $\left(1,465.83{ }^{\circ} \mathrm{C}\right.$ for the $\mathrm{R} 9$ stage). The early cultivar, i.e., BRS G58 presented the lowest thermal time to reach the complete anthesis $\left(841.75^{\circ} \mathrm{C}\right.$ for the R5.10 stage), beginning of the achenes filling $\left(912.63{ }^{\circ} \mathrm{C}\right.$ for the R7 stage) and the second with lower thermal time for physiological maturation $\left(1,179.93^{\circ} \mathrm{C}\right.$ for R9 stage), very close to cultivar BRS G60, which was the cultivar with the lowest thermal time for reaching the $\mathrm{R} 9$ stage $\left(1,174.49^{\circ} \mathrm{C}\right)$.

In a study performed by Sentelhas and Ungaro (1998), the thermal time for sunflower reaching the physiological maturity point in three cultivars was respectively of $1,713{ }^{\circ} \mathrm{C}, 1,743{ }^{\circ} \mathrm{C}$ and $1,848^{\circ} \mathrm{C}$, demonstrating that the cultivars currently used require less thermal time to reach the physiological maturation point. This fact was observed with Syn 045 cultivar that required $247^{\circ} \mathrm{C}$ less than the earlier cultivar of the previous study.

Evolution regarding precocity is noticeable in cultivars currently used, but the recommendation of cultivars with different cycles is prudent to reduce the loss of productive potential due to environmental stresses during critical developmental periods. Accordingly, if two cultivars are used for cultivation, the use of a medium (BRS G61 or CATISSOL 03) or late (Syn 045) and one early cultivar comprised in the third group (BRS 323, BRS G58, BRS G59, BRS G60 or MULTISSOL 02) can be recommended based on the thermal time.

\section{CONCLUSION}

There are differences for thermal time between the sunflower cultivars, demonstrating genetic variability in relation to the phenological development of cultivars. Different cultivar group formation is observed with the use of thermal time in comparison to calendar days as observed in the R5.1, R7 and R8 stages. The use of thermal time is recommended for greater precision in the classification of cultivar development.

\section{ACKNOWLEDGEMENTS}

We thank the Federal University of Santa Maria, the National Council for Scientific and Technological Development (CNPq) and the Research Incentive Fund (FIPE Junior - UFSM, FIPE Ard - UFSM and PIBIC UFSM) for granting financial resources. We are also thankful to the Brazilian Agricultural Research Corporation - EMBRAPA for the organization of the Sunflower National Trials.

\section{REFERENCES}

Alvares, C.A., Stape, J.L. and Sentelhas, P.C, 2013. Köppen's climate classification map for Brazil. Meteorol. Zeitschrift 22: 711-728.

Aquino, L. A., Júnior, V. C. S and Guerra, J. V. S, 2010. Estimativa da área foliar do girassol por método não destrutivo. Bragantia, Campinas. obtained from http://www.scielo.br/ em 27 de agosto de 2018.

Bartz, A. C., Muttoni, M and Alberto, C. M, 2017. Thermal time in sprinkler-irrigate lowland rice. Pesq. Agropec.bras., Brasília, v52,n.7: 475-484

Bencke, C. S. C. and Morellato, P. C., 2002. Comparação de dois métodos de avaliação da fenologia de plantas, sua interpretação e representação. Revista Brasil. Bot. V. 25, n. 3: 269-275

Bergamaschi, H. and Bergonci, J. I, 2017. As Plantas e o Clima: Princípios e aplicações. Agrolivros. 351p.

Carvalho, H. P., Camargo, R and Gomes, M.W.N, 2014.Classificação do ciclo de desenvolvimento de cultivares de cafeeiro através da soma térmica. Coffee Science, Lavras, v. 9,n.2: 237-244

Dalchiavon, F.C., Malacarne, B.J and Carvalho, C.G.P, 2015. Características agronômicas de genótipos de girassol (Helianthus annuus L.) em segunda safra no Chapadão do Parecis - MT. Sociedade de Ciência Agrária de Portugal. Obtido de http://www.scielo.mec.pt/ em 13 de agosto de 2018.

Deprá, M.S., Lopes, S. J and Noal, G, 2016. Modelo logístico de crescimento de cultivares criolas de milho e de progênies de meios-irmãos maternos em função da soma térmica. Ciência Rural, Santa Maria, V.46, n.1: 36-43

Ferreira, M.C., Martins, F.B and Campos, B, 2016. Métodos de soma térmica e estimativa do filocrono de duas cultivares de girassol. XII Congresso Nacional Meio Ambiente de Poços de Caldas. Obtido de http://www.meioambientepocos.com.br/ em 27 de julho de 2018.

Lucas, D. D. P., Heldwein, A. B and Hinnah, F. D, 2015. Estimation of leaf área index in the sunflower as a function of termal time. Revista Ciência Agronômica, v. 46, n. 2: 404-411

Miranda, M. N. and Junior, J. H. C, 2010. Soma térmica para o subperíodo semeadura - maturação de feijão cv. carioca em Colorado do Oeste, Rondônia. Pesquisa Agropecuária Tropical. Obtido de https://www.revistas.ufg.br/ em 28 de agosto de 2018.

Monteiro, José Eduardo B. A., 2009. Agrometeorologia dos Cultivos: O fator meteorológico na produção agrícola. Brasília - DF, $1^{\circ}$ Edição. 530 p.

Paula, F. L.M., Streck, N. A and Heldwein, A. B, 2005. Soma Térmica de algumas fases do ciclo de desenvolvimento da batata (Solanum tuberosum L.). Ciência Rural. Obtido de https://www.researchgate.net/ em 28 de agosto de 2018.

Pimentel, L., Borém, Al, 2018. Girassol: do plantio a colheita. Universidade Federal de Viçosa.

Sangoi, L. and Silva, P. R. F, 1986. Comparação entre métodos de cálculo de unidades térmicas e os dias do calendário da previsão de subperíodos de desenvolvimento do girassol. Pesquisa Agropecuária Brasileira. Obtido de https://seer.sct.embrapa.br/ em 22 de agosto de 2018.

Santos, H.G., Jacomine, P.K.T and Anjos, L.H.C, 2013. Sistema Brasileiro de Classificação de Solos. 3ed.rev.e ampl. Brasília. Embrapa

Schneiter, A. A. and Miller, J.F, 1981. Description of sunflow.er growth stages. Crop Science, Madison, n.21: 901-903.

Sentelhas, P.C. and Ungaro, M.R.G., 1998. Índices bioclimáticos para a cultura de girassol. Scientia Agricola. Obtido de http://www.ajbasweb.com/ em 13 de outubro de 2018

Souza, L.C., Costa, A.V.A and Moreira, W. K.O, 2016. Métodos de soma térmica na determinação de plastocrono de Helianthus annuus L. Cultivado em ambiente protegido em Capitão poço-Pa. Nucleus, v.136, n. 2: 143-152

Steinmetz, S., Cuadra, S. V and Almeida, I. R, 2017. Soma térmica e estádios de desenvolvimento da planta de grupos de cultivares de arroz irrigado. Agrometeoros, Passo Fundo, v. 25, n. 2: 405-414

Tomazetti, T. C., Rossarolla, M. D and Zeist, A. R, 2015. Fenologia e acúmulo térmico em videiras viníferas na região da Fronteira Oeste do Rio Grande do Sul. Pesq. Agropec. Bras., Brasília, v. 50, n. 11: 1033-1041

Trentin, R., Schreiber, F and Streck, N.A, 2008. Soma Térmica de subperíodos do desenvolvimento da planta de melancia. Ciência Rural. Obtido de http://www.scielo.br/ em 28 de agosto de 2018. 